\title{
HUBUNGAN GAYA KEPEMIMPINAN GURU DENGAN PRESTASI BELAJAR SISWA SEKOLAH DASAR
}

\author{
Asikin \\ SDN Teja II Rajagaluh Majalengka, Indonesia \\ asikin0120@gmail.com
}

\begin{abstract}
This study aims to determine the relationship of the teacher's situational leadership style in learning to the learning achievements of fifth grade elementary school students in the cluster of V, Rajagaluh 2019/2020 school year. The hypothesis of this study is that there is a positive relationship between the teacher's situational leadership style in learning and the fifth grade students' achievement in the fifth grade elementary school, Rajagaluh 2019/2020 school year. This research uses a quantitative research approach with data collection techniques using surveys. The results showed that the teacher's situational leadership style was significantly related to student achievement. So it can be concluded that the teacher's situational leadership style in learning has a positive relationship with the learning achievement of fifth grade students of the cluster of V Elementary School, Rajagaluh 2019/2020 school year.
\end{abstract}

Keywords: Leadership style, learning achievement.

\section{ABSTRAK}

Penelitian ini bertujuan untuk mengetahui hubungan gaya kepemimpinan situasional guru dalam pembelajaran terhadap prestasi belajar siswa kelas V Sekolah Dasar Se Gugus Lima, Rajagaluh tahun ajaran 2019/2020. Hipotesis penelitian ini adalah ada hubungan positif antara gaya kepemimpinan situasional guru dalam pembelajaran terhadap prestasi siswa kelas V Sekolah Dasar Se-Gugus Lima, Rajagaluh tahun ajaran 2019/2020. Penelitian ini menggunakan pendekatan penelitian kuantitatif dengan teknik pengumpulan data menggunakan survei. Hasil penelitian menunjukkan bahwagaya kepemimpinan situasional guru berhubungan signifikan dengan prestasi siswa. Sehingga dapat ditarik kesimpulan bahwa gaya kepemimpinan situasional guru dalam pembelajaran ada hubungan positif terhadap prestasi belajar siswa kelas V Sekolah Dasar Se-Gugus Lima, Rajagaluh tahun ajaran 2019/2020.

Kata Kunci: gaya kepemimpinan situasional, guru, prestasi belajar.

Submitted Feb 26, 2020 | Revised Mar 19, 2020 | Accepted Mar 21, 2020

\section{Pendahuluan}

Pendidikan merupakan salah satu komponen terpenting dalam hal memperbaiki kualitas bangsa. Hal itu disebabkan karena melalui pendidikan, akan mencetak sumber daya manusia yang unggul. Sumber daya manusia yang berkualitas merupakan aset pembangunan bangsa agar mampu menghadapi persaingan global (Muhardi, 2004). Apabila pendidikan di Indonesia sudah dapat mencetak generasi penerus bangsa yang berkualitas, maka akan dapat memajukan bangsa. Dalam pendidikan, sumber daya manusia dengan segala kemampuannya akan dikembangkan, dan dibentuk wataknya sehingga akan menjadi manusia yang seutuhnya.

Pendidikan memegang unsur penting untuk membentuk pola pikir, akhlak, dan perilaku manusia agar sesuai dengan norma-norma yang ada (Pusparini, dkk, 2018). Pendidikan lebih 
dari sekedar pengajaran, yang dapat dikatakan sebagai suatu proses transfer ilmu, transformasi nilai, dan pembentukan kepribadian dengan segala aspek yang dicakupnya (Nurkholis, 2013).

Komponen utama dalam pendidikan adalah guru, dan siswa. Siswa dilihat sebagai subjek didik, yang di mana nilai kemanusiaan sebagai individu dan sebagai makhluk sosial yang memiliki identitas moral yang harus dikembangkan, dalam mencapai tingkat optimal dan juga kriteria kehidupan sebagai manusia dan warga negara yang diharapkan (Muhaimin, dkk, 2005). Guru harus mampu membimbing dan mendidik siswa untuk mencapai kompetensi yang telah ditetapkan pada setiap pembelajaran yang dilaksanakan, karena pembelajaran dianggap berhasil jika terjadi perubahan perilaku yang positif pada diri siswa. Dalam hal ini, pembelajaran yang dilaksanakan guru harus mampu membawa siswa mencapai prestasi belajarnya. Namun beberapa pembelajaran yang dilakukan oleh guru belum mencapai prestasi yang diharapkan. Kondisi ini terjadi pada siswa kelas V SD di gugus lima Rajagaluh. Berdasarkan hasil observasi diperoleh temuan bahwa prestasi belajar siswa masih rendah. Rendahnya prestasi belajar siswa tersebut tercermin dari beberapa hasil tes siswa menunjukkan persentase ketuntasan belajar yang masih rendah. Dari observasi terbut juga diperoleh temuan bahwa pembelajaran yang dilakukan guru masih cara mengajar dengan klasikal. Di mana guru menjelaskan materi pelajaran dan memberi tugas kepada siswa. Dalam memberikan tugas, guru kurang memberikan bimbingan dan arahan kepada siswanya. Walaupun guru sudah dapat mengidentifikasi siswa memiliki tingkat kematangan yang berbeda-beda, namun guru belum mampu mengelola pembelajaran dengan baik. Guru belum memiliki gaya kepemimpinan yang sesuai dengan situasi yang dihadapi. Dalam hal ini, guru belum optimal dalam menerapkan gaya kepemimpinan dalam pembelajaran.

Dari paparan di atas, maka guru merupakan komponen yang sangat menentukan keberhasilan suatu pembelajaran. Guru sebagai garda terdepan di bidang pendidikan, harus terus melakukan pengembangan diri secara berkelanjutan agar menjadi guru yang mampu menghasilkan sumber daya manusia yang berkualitas (Nahdi \& Cahyaningsih, 2019). Bangsa yang besar dan berkualitas ditentukan oleh peran dan pengaruh guru dalam bidang pendidikan (Sundari, 2017). Di sekolah, guru mempunyai hubungan yang sangat dekat dengan siswa dalam upaya pendidikan sehari-hari di sekolah. Di mana guru sebagai penanggung jawab keterlaksanaan proses pembelajaran di kelas. Oleh sebab itulah guru berperan penting dalam keberhasilan pembelajaran.

Dalam pembelajaran, Guru sebagai pemegang kunci utama pembelajaran harus bisa mengelola kelas dengan baik (Pamela, dkk, 2019). Pengelolaan kelas merupakan keterampilan guru menciptakan dan memelihara kondisi belajar yang optimal dan mengembalikannya manakala terjadi hal - hal yang dapat mengganggu suasana pembelajaran (Sanjaya (2009), dalam Istihana (2015). Peran guru tidak hanya membuat rencana pembelajaran, menyampaikan materi dan memberi nilai pada siswa saja, tetapi guru harus mengelola kelasnya. Mengelola kelas harus disertai dengan jiwa kepemimpinan supaya kelas dapat berjalan sesuai dengan tujuan yang telah ditentukan. Kepemimpinan guru yang baik dapat menciptakan efektifitas dan efesiensi pembelajaran serta dapat membentuk disiplin peserta didik dan guru itu sendiri (Supardi, 2014: 54). Namun tidak semua orang memiliki jiwa kepemimpinan yang baik. Seorang pemimpin yang dibutuhkan bukan hanya pintar kognitifnya saja, melainkan matang secara emosionalnya juga. 
Kepemimpinan merupakan kemampuan seseorang yang menduduki jabatan sebagai pemimpin untuk memimpin yang terdiri dari mengarahkan, membimbing dan mempengaruhi sesuatu perilaku orang yang dipimpin untuk berfikir dan bertindak seemikian rupa melalui perilaku yang positif guna menapai tujuan. Seorang pemimpin sebaiknya mempunyai kemampuan dalam memimpin yang dapat menunjang terapainya tujuan yang diaharapkan (Siagian, 2000). George Terry dalam Vaithzal Rivai yang mengemukakan bahwa kepemimpinan adalah kegiatan dalam mempengaruhi orang lain untuk bekerja keras dengan penuh kemauan untuk tujuan kelompok (Rivai dan Murni, 2012).

Gaya kepemimpinan akan menentukan sejauhmana efektivitas kepemimpinan, karena seorang pemimpin yang memiliki gaya kepemimpinan yang tepat, akan dapat memaksimalkan kepemimpinannya. Menurut (Rohani, 2004: 130) gaya atau tipe kepemimpinan ada tiga yaitu: 1) gaya kepemimpinan autokratik (otoriter), 2) gaya kepemimpinan demokratik atau partisipatif, dan 3) gaya kepemimpinan bebas (laissez, faire). Sebagian besar para ahli mengungkapkan bahwa tidak ada satu pun gaya yang paling tepat yang dapat mengatasi permasalahan yang muncul dalam berbagai situasi yang berbeda. Gaya kepemimpinan diperlukan untuk mempengaruhi perilaku siswa. Guru sebagai pemimpin dalam kegiatan belajar mengajar di dalam kelas akan memiliki pola perilaku yang khas dalam mempengaruhi para siswanya yang disebut gaya kepemimpinan guru. Gaya kepemimpinan guru adalah perilaku atau tindakan yang dilakukan oleh guru dalam pembelajarannya yang disesuaikan dengan kebutuhan berdasarkan karakteristik siswa. Pola tindakan yang perlu dimiliki guru adalah pola tindakan yang berorientasi pada tugas, dan yang berorientasi pada hubungan. Pola tindakan yang berorientasi pada tugas, memiliki tujuan untuk membantu siswa yang memiliki kemampuan melakukan tugas rendah untuk dapat menyelesaikan tugasnya dengan baik .Sedangkan pola tindakan yang berorientasi pada hubungan, bertujuan untuk kegiatan dalam pembelajaran situasi kelas menjadi terkondisi dengan baik sehingga tercapai tujuan yang telah ditentukan.

Guru masih memperlakukan siswa itu sama. Hal tersebut senada dengan Wikipedia (2013) yang mengatakan bahwa sistem pendidikan klasik yang dilakukan di sekolah kurang memperhatikan masalah perbedaan individual, umumnya pelaksanaan pembelajaran di kelas dengan melihat siswa sebagai individu dengan kemampuan rata-rata, kebiasaan yang kurang lebih sama, demikian pula pengetahuannya. Seharusnya guru berkeliling dalam kelas saat siswa mengerjakan soal latihan untuk membimbing dan memberi arahan kepada siswa yang berkemampuan rendah. Dengan begitu siswa akan merasa mendapatkan perhatian lebih dari guru sehingga akan memotivasi siswa untuk maju menjadi lebih baik.

Pada umumnya proses pendidikan dan pengajaran di sekolah berjalan klasikal, artinya guru menghadapi siswa dalam jumlah besar atau banyak dalam waktu yang sama, dan materi yang sama. Sehingga guru beranggapan bahwa kemampuan, kesiapan, dan kematangan, serta kecepatan belajar siswa itu sama. Akhirnya, ada beberapa siswa yang belum mengerti materi yang diajarkan namun guru sudah berganti materi selanjutnya.

Selain itu kebanyakan guru masih belum begitu paham akan penerapan gaya kepemimpinan dalam pembelajaran yang disesuaikan dengan tingkat kematangan siswa. Sehingga guru hanya menerapkan gaya kepemimpinan yang menyamaratakan siswa itu sama. Karena belum paham akan gaya kepemimpinan yang disesuaikan dengan tingkat kematangan 
siswa, maka guru juga belum tahu akan hubungan gaya kepemimpinan situasional dalam pembelajaran terhadap prestasi belajar siswa.

\section{Metode Penelitian}

Pendekatan penelitian yang akan digunakan dalam penelitian ini adalah pendekatan kuantitatif dengan jenis penelitian korelasi. Penelitian korelasi adalah penelitian yang dilakukan untuk menggabungkan dua variabel atau lebih (Misbahudin \& Hasan, 2014). Penelitian ini melibatkan tindakan pengumpulan data guna menentukan, apakah ada hubungan dan tingkat hubungan antara dua variabel atau lebih (Sukardi, 2014). Teknik yang digunakan dalam penelitian ini menggunakan teknik survei. Dalam survei, informasi dikumpulkan dari responden dengan menggunakan kuesioner. Umumnya, pengertian survei dibatasi pada penelitian yang datanya dikumpulkan dari sampel atas populasi untuk mewakili seluruh populasi untuk mewakili seluruh populasi. Ini berbeda dengan sensus yang informasinya dikumpulkan dari seluruh populasi.

Populasi dalam penelitian ini adalah siswa kelas V Sekolah Dasar di gugus Lima yang siswanya berjumlah 136 dari 5 sekolah. Data tersebut diperoleh peneliti berdasarkan observasi yang telah dilaksanakan. Dalam penelitian ini penulis mengambil sampel menggunakan tabel Kerjlie dan Morgan dengan taraf kesalahan 5\% dari 136 jumlah siswa, pengambilan sampel sejumlah 101 orang. Supaya diperoleh sampel yang tidak menyimpang maka dalam penelitian ini dipergunakan teknik pengambilan sampel menggunakan teknik random sampling. Dalam hal ini seluruh siswa mendapat kesempatan yang sama untuk dipilih sebagai sampel.

\section{Hasil dan Pembahasan}

Berdasarkan hasil pengolahan data variabel prestasi belajar siswa diperoleh skor terendah 81 dan skor tertinggi 109. Berdasarkan distribusi skor variabel prestasi belajar siswa diperoleh skor rata-rata sebesar 97,33 nilai tengah (median) 98,00 nilai yang sering muncul (mode) 101 dan simpangan baku (standar deviation) 6.864. Untuk menginterpretasikan data secara kualitatif dilakukan dengan membandingkan skor rata-rata (mean) variabel komitmen dengan skor ideal maksimal dikali 100\%, maka diperoleh hasil 89,29\%. Hal ini berarti prestasi belajar siswa kelas V SD di gugus Lima Rajagaluh berada pada kategori “Tinggi” yaitu sebesar $89,29 \%$ dari skor ideal.

Berdasarkan hasil pengolahan data variabel kepemimpinan guru dalam mengelola kelas diperoleh skor terendah 99 dan skor tertinggi 121. Berdasarkan distribusi skor kepemimpinan guru diperoleh skor rata-rata (mean) sebesar 106,86, nilai tengah (median) 107,00, nilai yang sering muncul (mode) 109, dan simpangan baku (standar deviation) 4641. Untuk menginterpretasikan data secara kualitatif dilakukan dengan membandingkan skor rata-rata (mean) variabel kepemimpinan guru dengan skor ideal maksimal dikali 100\%, maka diperoleh hasil 88,31\%. Hal ini berarti kepemimpinan guru SD kelas V di gugus Lima Rajagaluh berada pada kategori "cukup" yaitu sebesar 88,31\% dari skor ideal.

Untuk dapat disimpulkan apak terdapat hubungan yang siginifikan antara kepemimpinan guru dan prestasi belajar siswa maka dilakukan analisis statistik secara inferensial. Analisis statistik yang digunakan yaitu uji korelasi dengan terlebih dahulu dilakukan uji noramlitas data. 
Pengujian normalitas dilakukan dengan menggunakan lilliefors test. Taraf signifikansi yang digunakan sebagai dasar menolak atau menerima keputusan normal atau tidaknya suatu distribusi adalah 0,05 . Untuk kriteria pengujian yang diambil berdasarkan nilai probabilitas.

Jika probabilitas (sig) $>0,05$, maka $\mathrm{H} 0$ diterima

Jika probabilitas (sig) < 0,05, maka $\mathrm{H} 0$ ditolak

Berikut disajikan Rekapitulasi hasil perhitungan Uji Normalitas pada table di bawah ini.

Tabel 1. Rekapitulasi perhitungan Uji Normalitas

\begin{tabular}{lll}
\hline Variabel & Sig. & Kesimpulan \\
\hline Kepemimpinan Guru & 0,615 & Normal \\
Prestasi belajar siswa & 0,591 & Normal \\
\hline
\end{tabular}

Berdasarkan hasil olah data menggunakan SPSS 20 di atas menunjukkan bahwa Sig $>$ 0,05, maka $\mathrm{H}_{0}$ diterima. Dapat disimpulkan bahwa variabel kepemimpinan guru berdistribusi normal yaitu $0,615>0,05$ dan prestasi belajar siswa yaitu $0,591>0,05$ juga bersitribusi normal.

Selanjutnya perhitungan uji korelasi untuk melihat hubungan kedua variabel menggunakan teknik Pearson Correlation. Hasil perhitungannya disajikan pada tabel di bawah ini.

Tabel 2. Hasil perhitungan Pearson Correlation

\begin{tabular}{lllll}
\hline Variabel & Analisis & r & Sig. & Kesimpulan \\
\hline $\begin{array}{l}\text { Kepemimpinan guru dan } \\
\text { prestasi belajar siswa }\end{array}$ & Pearson Correlation & 0,448 & 0,007 & $\begin{array}{l}\text { Terdapat } \\
\text { hubungan }\end{array}$ \\
\hline
\end{tabular}

Hasil uji korelasi di atas menunjukan bahwa terdapat hubungan antara kepemimpinan guru dalam mengelola kelas dengan prestasi belajar siswa kelas V SD se-gugus Lima Rajalgaluh

Berdasarkan hasil analisis tersebut, bahwa gaya kepemimpinan situasional guru mempunyai pengaruh dan mempunyai hubungan bagi prestasi siswa. Guru mempunyai peran besar dalam pengelolaan kelas. Gaya kepemimpinan merupakan faktor penting dalam melakukan tugas pengelolaan kelas karena dengan adanya gaya kepemimpinan maka kegiatan belajar mengajar dapat berjalan secara efektif dan efisien. Guru perlu meningkatkan kemampuannya dalam menggunakan gaya kepemimpinan yang variatif yang disesuaikan dengan kebutuhan dalam kegiatan belajar mengajar. dengan adanya peningkatan gaya kepemimpinan, maka guru dapat meningkatkan efektivitas pengelolaan kelas. Hal tersebut berarti bahwa prestasi siswa akan terus meningkat seiring dengan peningkatan gaya kepemimpinan variatif yang dilakukan oleh guru.

\section{Kesimpulan}

Terdapat hubungan gaya kepemimpinan situasional guru dalam pembelajaran dengan prestasi siswa. Dalam artian terdapat pengaruh yang positif dan signifikan antara gaya kepemimpinan situasional guru terhadap prestasi siswa kelas V Sekolah Dasar se-gugus Lima, Kecamatan, Rajagaluh tahun ajaran 2019/2020. 


\section{Daftar Pustaka}

Istiana. (2015). Pengelolaan Kelas di Madrasah Ibtidayah. Jurnal Pendidikan dan Pembelajaran Dasar, 2(2), 267-284.

Misbahuddin \& Hasan, I. (2014). Analisis Data Penelitian dengan Statistik. Jakarta; BumiAksara.

Muhaimin, dkk. (2005). Strategi Belajar Mengajar. Surabaya: Citra Media.

Muhardi. (2004). Kontribusi Pendidikan Dalam Meningkatkan Kualitas Bangsa Indonesia. Mimbar, 20(4), 478 - 492.

Nahdi, D.S. \& Cahyaningsih, U. (2019). Keterampilan Guru SD Dalam Menghadapi Era Revolusi Industri 4.0. Social, Humanities, and Educational Studies (SHEs): Conference Series, 57-63.

Nurkholis. (2013). Pendidikan Dalam Upaya Memajukan Teknologi. Jurnal Kependidikan, 1 (1), 24-44.

Pamela, dkk. (2019). Keterampilan Guru Dalam Mengelola Kelas. Edustream: Jurnal Pendidikan Dasar, 3(2), 23-30.

Pusparini, dkk. (2018). Pengaruh Model Pembelajaran Problem Based Learning (PBL) Terhadap Kemampuan Berpikir Kritis Siswa Pada Materi Sistem Koloid. Jurnal Riset Pendidikan Kimia, 8(1), 35-42.

Rivai, V. \& Murni, S. (2012). Education Management Analisis Teori dan Praktik. Jakarta: PT Raja Grafindo Persada.

Sanjaya. Wina. 2009. Kurikulum dan Pembelajaran Teori dan Praktik Pengembangan Kurikulum Tingkat Satuan Pendidikan (KTSP). Kencana. Jakarta.

Sukardi. (2014). Metodologi Penelitian Pendidikan. Jakarta; Bumi aksara.

Sundari, F. (2017). Peran Guru Sebagai Pembelajar Dalam Memotivasi Peserta Didik Usia SD. Prosiding Diskusi Panel Pendidikan "Menjadi Guru Pembelajar", 60-76.

Supardi. (2014). Kinerja guru. Cet. II: Jakarta: Rajawali Pers. 